\title{
PENERAPAN KOMUNIKASI TERAPEUTIK PADA PASIEN HALUSINASI DI RUMAH SAKIT JIWA TAMPAN PROPINSI RIAU
}

\author{
Juli Widiyanto, Zakiyah Rizki \\ D III Keperawatan Universitas Muhammadiyah Riau \\ Email: juliwidiyanto@umri.ac.id
}

\begin{abstract}
Therapeutic communication is a communication made by nurses to patients who previously had been planned in advance. Therapeutic Communication aims to reduce the burden of perceived or experienced by the patient. While hallucination is a perception disorder that does not actually exist in reality. With the Application of Therapeutic Communication will be an alternative to overcome the problems associated with hallucinations patients. Aim of study is to look at describe Application of Therapeutic Communication Hallucinations in Patients at the Tampan Mental Hospital of Riau Province. Kind of Research used is simple description with time series desain and the sampling technique is simple random sampling technique whice are mostly nurses samples in this study who were at the Tampan Mental Hospital of Riau province are 38 respondents. The Instrumen to tool uses observation sheets and indepth interview. The Results of research has been indicated that describe Application of Therapeutic Communication in Patients Hallucinations at The Tampan Mental Hospital of Riau Province mayoritas is applied therapeutic communication as much as 24 respondents (63.2\%) whereas in the category does not apply as much as 14 respondents (36.8\%). Based on the results of these studies are expected to nurses at the Tampan Mental Hospital of Riau Province to improve the application of therapeutic communication is done to patients who experience mental illness of his special patients experiencing hallucinations.
\end{abstract}

Keywords: Application, Therapeutic Communication, Patient hallucinations.

\section{PENDAHULUAN}

Kesehatan adalah hak dasar manusia yang merupakan karunia Allah SWT yang sangat tinggi nilainya. Kesehatan juga merupakan salah satu unsur esensial dalam penentuan kualitas Sumber Daya Manusia (SDM), oleh karena itu perlu di pelihara dan di tingkatkan. Kesehatan banyak di tentukan oleh prilaku manusia dan lingkungannya, untuk itu diperlukan upaya untuk meningkatkan kemauan, kesadaran dan kemampuan sehingga setiap orang, keluarga serta masyarakat dapat mandiri dalam meningkatkan kesehatan (Purwakarta, 2003 dalam Parmanda, 2013).

Tuntutan dan masalah hidup yang semakin meningkat serta perkembangan teknologi yang pesat menjadi stresor pada kehidupan manusia. Jika individu tidak mampu melakukan koping dengan adaptif, maka individu berisiko mengalami gangguan jiwa. World Health Organization (WHO) (2001) menyatakan bahwa sekitar 450 juta orang di dunia memiliki gangguan mental. Fakta lainnya adalah 25 persen penduduk diperkirakan akan mengalami gangguan jiwa pada usia tertentu selama hidupnya. Gangguan jiwa mencapai 13 persen dari penyakit di dunia, dibandingkan TBC $(7,2$ persen), kanker (5,8 persen), jantung $(4,4$ persen) maupun malaria (2,6 persen) dan masalah gangguan jiwa dapat terus meningkat jika tidak dilakukan penanganan.

Gangguan jiwa (mental disorder) merupakan salah satu dari empat masalah kesehatan utama di negara-negara maju, modern dan industri yaitu penyakit degeneratif, kanker, gangguan jiwa, dan kecelakaan. Gangguan jiwa tidak dianggap sebagai gangguan yang menyebabkan kematian secara langsung, namun beratnya gangguan tersebut dalam arti ketidakmampuan serta invaliditas baik secara individu maupun kelompok akan menghambat pembangunan, karena mereka tidak produktif dan tidak efisien (Hawari, 2006).

Skizofrenia adalah penyakit neurologi yang mempengaruhi persepsi, cara berpikir, bahasa, emosi, dan perilaku sosial pasien (Yosep, 2011). Berdasarkan data The American Psychiatric Association, di Amerika Serikat terdapat 300 ribu pasien skizofrenia yang mengalami episode akut setiap tahun. Angka kematian pasien skizofrenia 8 kali lebih tinggi dari angka kematian penduduk pada umumnya. Pasien 
skizofrenia yang mencoba melakukan bunuh diri sebanyak 20-30 persen, dan 10 persen di antaranya berhasil (Lukita, 2012).

Gangguan jiwa tersebar hampir merata di seluruh dunia, termasuk di wilayah Asia Tenggara. Berdasarkan data dari World Health Organization hampir satu per tiga dari penduduk di wilayah Asia Tenggara pernah mengalami gangguan neuropsikiatri (Yosep, 2011). Berdasarkan Riset Kesehatan Dasar (Riskesdas, 2013) Prevalensi gangguan jiwa berat pada penduduk Indonesia 1,7 per mil. Gangguan jiwa berat terbanyak di DI Yogyakarta, Aceh, Sulawesi Selatan, Bali, dan Jawa Tengah. Proporsi gangguan ini yang pernah dipasung pada gangguan jiwa berat 14,3 persen dan terbanyak pada penduduk yang tinggal di perdesaan (18,2 persen), serta pada kelompok penduduk dengan indeks kepemilikan terbawah (19,5 persen). Prevalensi gangguan mental emosional pada penduduk Indonesia 6,0 persen. Provinsi dengan prevalensi ganguan mental emosional tertinggi adalah Sulawesi Tengah, Sulawesi Selatan, Jawa Barat, DI Yogyakarta, dan Nusa Tenggara Timur.

Indikator kesehatan jiwa yang dinilai pada Riskesdas 2013 antara lain gangguan jiwa berat, gangguan mental emosional serta cakupan pengobatannya. Gangguan jiwa berat adalah gangguan jiwa yang ditandai oleh terganggunya kemampuan menilai realitas atau tilikan (insight) yang buruk. Gejala yang menyertai gangguan ini antara lain berupa halusinasi, ilusi, waham, gangguan proses pikir, kemampuan berpikir, serta tingkah laku aneh, misalnya agresivitas atau katatonik. Gangguan jiwa berat dikenal dengan sebutan psikosis dan salah satu contoh psikosis adalah skizofrenia.

Di Indonesia, Departemen Kesehatan RI (2008) mencatat bahwa 70 persen gangguan jiwa terbesar adalah Skizofrenia. Menurut Arif (2006) mengungkapkan bahwa 99 persen pasien yang dirawat di rumah sakit jiwa adalah pasien dengan diagnosis medis skizofrenia. Lebih dari 90 persen pasien skizofrenia mengalami halusinasi (Yosep, 2011). Menurut Stuart \& Laraia (2005) menyatakan bahwa pasien dengan diagnosis medis skizofrenia sebanyak 20 persen mengalami halusinasi pendengaran dan penglihatan secara bersamaan, 70 persen mengalami halusinasi pendengaran, 20 persen mengalami halusinasi penglihatan, dan 10 persen mengalami halusinasi lainnya.

Di Riau jumlah kunjungan gangguan jiwa pada tahun 2012 di Provinsi Riau sebanyak 18.343, mengalami penurunan dibandingan tahun 2011 yang mencapai 29.727 kunjungan. Kunjungan terbanyak di rumah sakit yaitu 10.479 kunjungan (57.13 persen) (Dinas Kesehatan Provinsi Riau, 2012). Berdasarkan data yang di peroleh pada survey awal pada tanggal 3 April 2014 menyatakan bahwa jumlah pasien yang menderita halusinasi berjumlah 1764 pasien yang terdiri dari ruangan Sebayang (330), indragiri (291), kuantan (547), siak (104), kampar (492). Halusinasi merupakan peringkat pertama dari berbagai jumlah pasien yang mengalami gangguan jiwa (39,58 persen), resiko perilaku kekerasan $(29,14$ persen), isolasi sosial (7,66 persen), harga diri rendah kronik $(12,58)$, waham (1,296 persen), DPD $(9,77)$.

Berdasarkan data tersebut diketahui bahwa jenis halusinasi yang paling banyak diderita oleh pasien dengan skizofrenia adalah pendengaran. Halusinasi merupakan bentuk yang paling sering dari gangguan sensori persepsi. Pasien yang mengalami halusinasi biasanya merasakan sensori palsu berupa suara, penglihatan, pengecapan, perabaan atau penghiduan (Direja, 2011). Sensori dan persepsi yang dialami pasien tidak bersumber dari kehidupan nyata, tetapi dari diri pasien itu sendiri. Hasil penelitian terdahulu yang dilakukan oleh Sulastri (2010) dalam penelitiannya terhadap 30 responden didapatkan bahwa penerapan asuhan keperawatan dapat mengontrol gejala halusinasi pasien. Berdasarkan hasil penelitian didapatkan bahwa pada kelompok intervensi terjadi peningkatan nilai kemampuan mengontrol halusinasi, sedangkan pada kelompok kontrol tidak mengalami perubahan. Hasil dari kedua penelitian tersebut sama-sama menunjukkan bahwa ada perbedaan kemampuan pasien dalam mengontrol halusinasi sebelum dan setelah diterapkan strategi pelaksanaan halusinasi. 
Menurut Chaery (2009) dampak yang dapat ditimbulkan oleh pasien yang mengalami halusinasi adalah kehilangan kontrol dirinya. Pasien akan mengalami panik dan perilakunya dikendalikan oleh halusinasi. Pada situasi ini pasien dapat melakukan bunuh diri (suicide), membunuh orang lain (homicide),bahkan merusak lingkungan untuk memperkecil dampak yang ditimbulkan halusinasi. Sejalan dengan paradigma sehat yang dicanangkan departemen kesehatan yang lebih menekankan upaya proaktif melakukan pencegahan daripada menunggu di rumah sakit, kini orientas upaya kesehatan jiwa lebih pada pencegahan (preventif) dan promotif (Wahyuni, 2007 dalam Lukita 2012).

Perawat sebagai komponen penting dalam proses keperawatan dan orang yang terdekat dengan pasien harus mampu berkomunikasi baik secara verbal maupun non verbal dalam membantu penyembuhan pasien. Menurut Nurjannah (2001) dalam Diana (2006), mampu terapeutik berarti seorang perawat yang mampu melakukan atau mengkomunikasikan perkataan, perbuatan, atau ekspresi yang memfasilitasi penyembuhan pasien.

Berdasarkan penelitian yang dilakukan oleh Sitorus (2000) dalam Husna (2009) tentang kepuasan pasien dan keluarga menunjukan bahwa tingkat kepuasan dengan ketegori baik (16,9 persen), kategori sedang ( 81,5 persen) dan kategori kurang (1,55 persen). Sedangkan hasil penelitian yang dilakukan Utami (2006) di Rumah sakit Sukoharjo- Surakarta tentang sikap komunikasi perawat terhadap pasien menunjukan bahwa sikap baik (23,47 persen), cukup (76,53 persen), dan kurang (0 persen). Penjelasan atau informasi yang kurang dari perawat tentang kondisi pasien, dapat menimbulkan ketidakpuasan pasien terhadap pelayanan keperawatan yang diberikan, karena sesungguhnya pasien mempunyai hak untuk mengetahui segala sesuatu yang berhubungan dengan keadaan penyakit yang dideritanya. Sehingga peneliti tertarik untuk meneliti tentang "Penerapan Komunikasi Terapeutik Pada Pasien Halusinasi di Rumah Sakit Jiwa Tampan Provinsi Riau".

\section{METODOLOGI PENELITIAN}

Desain penelitian yang digunakan dalam penelitian ini adalah Deskriptif sederhana dengan rancangan time series, merupakan studi epidemiologi deskriptif tentang serangkaian kasus, yang berguna untuk mengdeskripsikan spektrum penyakit atau kejadian, manifestasi klinis, perjalanan klinis, dan prognosis kasus. Case series banyak dijumpai dalam literatur kedokteran klinik (Murti, 2011).

Tujuan penelitian ini adalah untuk mengetahui penerapan komunikasi terapeutik pada pasien halusinasi di Rumah Sakit Jiwa Tampan Provinsi Riau. Instrumen yang digunakan adalah lembar observasi dan indeph interview. Menurut Hidayat (2011), lembar observasi adalah cara pengumpulan data dengan mengadakan melakukan pengamatan secara langsung kepada responden penelitian untuk mencari perubahan atau hal-hal yang akan diteliti. Sedangkan indepth interview adalah metode pengumpulan data dengan cara mewawancarai langsung responden yang diteliti, metode ini memberikan hasil secara langsung (Hidayat, 2011). Dalam analisa data peneliti menggunakan analisa univariate, yaitu analisis yang dilakukan terhadap tiap variabel dari hasil penelitian yang hanya menggunakan hasil perhitungan terhadap tiap variabel dari hasil penelitian tiap variabel.

\section{HASIL DAN PEMBAHASAN Hasil}

Tabel 1.

Jenis Kelamin Responden di Rumah Sakit Jiwa Tampan Provinsi Riau

\begin{tabular}{cccc}
\hline No & Jenis Kelamin & F & $\%$ \\
\hline 1 & Laki-Laki & 8 & 21.1 \\
2 & Perempuan & 30 & 78.9 \\
\hline & Total & 38 & 100.0 \\
\hline
\end{tabular}

Berdasarkan tabel diatas, jenis kelamin responden di Rumah Sakit Jiwa Tampan Provinsi Riau mayoritas Perempuan yaitu 30 responden $(78.9 \%)$. 
Tabel 2.

Lama Bekerja Responden di Rumah Sakit Jiwa Tampan Provinsi Riau

\begin{tabular}{cccc}
\hline No & Lama Bekerja & F & $\%$ \\
\hline 1 & $2-5$ Tahun & 7 & 18.4 \\
2 & 6-10 Tahun & 12 & 31.6 \\
3 & $>10$ Tahun & 19 & 50.0 \\
\hline & Total & 38 & 100.0
\end{tabular}

Berdasarkan tabel diatas, tampak bahwa lama bekerja responden di Rumah Sakit Jiwa Tampan Provinsi Riau mayoritas > 10 tahun yaitu 19 responden $(50.0 \%)$.

Tabel 3.

Pendidikan Responden di Rumah Sakit Jiwa Tampan Provinsi Riau

\begin{tabular}{cccc}
\hline No & Pendidikan & F & $\%$ \\
\hline 1 & DIII & 31 & 81.6 \\
2 & SI & 1 & 2.6 \\
3 & SI+Ns & 6 & 15.8 \\
\hline & Total & 38 & 100.0 \\
\hline
\end{tabular}

Berdasarkan table diatas, tampak bahwa Pendidikan responden di Rumah Sakit Jiwa Tampan Provinsi Riau mayoritas adalah D III yaitu 31 responden $(81.6 \%)$.

Tabel 4.

Penerapan Komunikasi Terapeutik Pada Pasien Halusinasidi Rumah Sakit Jiwa Tampan Provinsi

\begin{tabular}{cccc}
\multicolumn{4}{c}{ Riau } \\
\hline No & Kategori Pengetahuan & F & $\%$ \\
\hline 1 & Diterapkan & 24 & 63.2 \\
2 & Tidak & 14 & 36.8 \\
\hline & Total & 38 & 100.0 \\
\hline
\end{tabular}

Berdasarkan tabel diatas, tampak bahwa mayoritas responden menerapkan komunikasi terapeutik di Rumah Sakit Jiwa Tampan Provinsi Riau yaitu 24 responden (63.2\%).

\section{Pembahasan}

Berdasrkan hasil penelitian menunjukan bahwa penerapan komunikasi terapeutik di Rumah sakit jiwa tampan yang diterapkan sebanyak $24(63.16 \%)$ dan tidak diterapkan sebanyak 14 (36.84\%).
Hasil penelitian ini sesuai dengan penelitian yang pernah dilakukan oleh Agustin (2009) yang berjudul " Hubungan pelaksanaan komunikasi terapeutik dengan tingkat kecemasan pasien rawat inap di BP RSUD Kebumen" dapat terlihat bahwa penerapan komunikasi terapeutik sudah dilakukan yang menghasilkan pelaksanaan komunikasi terapeutik dari 30 responden dan sebanyak 16 responden $(53,44 \%)$ yang menyatakan bahwa penerapan komunikasi terapeutik perawat baik. faktor pendukung dari pelaksanaan komunikasi terapeutik adalah perawat yang berpendidikan DIII Keperawatan untuk menerapkan komunikasi terapeutik karena perawat yang berpendidikan DIII Keperawatan sudah mengerti dan mengetahui apa dan bagaimana penerapan komunikasi terapeutik. Dalam profesi keperawatan, komunikasi sangat penting antara perawat dengan perawat, perawat dengan pasien, khususnya komunikasi antar perawat dengan pasien dimana dalam komunikasi itu perawat dapat menemukan beberapa solusi dari permasalahan yang sedang dialami pasien, Komunikasi memegang peranan yang sangat penting dalam pelayanan keperawatan, bahkan dapat dikatakan komunikasi merupakan kegiatan mutlak dan menentukan bagi hubungan ataupun interaksi perawat ke pasien dalam menunjang kesembuhan pasien (Khotimah, 2012).

Hasil penelitian ini didukung penelitian Mulyaningsih (2005) yang berjudul “ Menciptakan Hubungan Terapeutik Antara Perawat Dengan Klien" yang menghasilkan komunikasi terapeutik perawat yang berpendidikan DIII Keperawatan ternyata cukup dengan persentase $(55 \%)$.

Hal tersebut diperkuat dengan hasil indepth interview yang dilakukan pada saat penelitian dan dilakukan beberapa responden dengan pertanyaan (apakah penerapan komunikasi terapeutik sudah dilakukan di Rumah Sakit Jiwa Tampan Provinsi Riau ini?) "Penerapan komunikasi terapeutik di Rumah Sakit Jiwa Tampan alhamdullillah sudah dilakukan" (Informan 1) Saya rasa sudah bagus penerapan komunikasi terapeutik di rumah sakit jiwa tampan ini, pada saat sebelum ke pasien pun kita 
seharusnya memakai komunikasi terapeutik jangan langsung ke SP nya" (Informan 1) "Kalau penerapan komunikasinya sudah, tinggal kita melihat kondisi pasien selanjutnya apakah memungkinkan kita melakukan komunikasi tersebut apa tidak" (Informan 2)

Hal ini diperkuat dengan penelitian yAzizah (2013) membuktikan bahwa komunikasi terapeutik adalah hubungan antara perawat dan pasien dalam proses komunikasi perilaku orang lain yang tujuannnya merubah perilaku dalam pencapaian kesehatan yang optimal. Namun dalam melakukan komunikasi terapeutik ini perawat memiliki kendala dalam melakukan komunikasi yang sifat nya terapeutik, salah satu kendala yang paling sering dijumpai pada saat melakukan komunikasi kepada pasien yang mengalami halusinasi adalah pada saat halusinasi pasien lebih dominan menguasai diri pasien dan pada akhirnya konsentrasi pasien terpecah,dan pasien pun sulit mendapatkan informasi yang di berikan oleh perawat.

Hal ini di perkuat hasil indepth interview yang menyatakan bahwa kesulitan yang akan dialami oleh perawat pada saat melakukan komunikasi terapeutik kepada pasien yang mengalami halusinasi adalah pada saat halusinasi lebih dominan mengusai diri pasien.“ Kesulitan terhadap pasien yang mengalami halusinasi apabila lebih kuat halusinasinya yang mengontrol dirinya, terkadang kita disitu mengalami kesulitannya, karna dia memang sudah terfokus dengan halusinasi. Tapi pada umumnya kalau kita sudah tau pasien itu sedang mengalami halusinasi melakukan komunikasinya di luar trali” (Informan 3) “

Melakukan komunikasi terapeutik kepada pasien halusinasi harus memperhatikan: kontak pandang dengan melakukan kontak pandang akan mencerminkan rasa menghargai kepada pasien., yang kedua, mencondongkan tubuh ke depan dengan posisi yang seperti ini akan menunjukkan kepedulian dan keinginan untuk mendengarkan sesuatu yang dirasakan oleh pasien, yang ketiga menjaga keterbukaan dengan menjaga keterbukaan akan meningkatkan kepercayaan pasien kepada para perawat (Machfoedz, 2009). Hal ini sesuai dengan hasil indepth interview yang berkaitan dengan hal yang harus diperhatikan dalam melakukan komunikasi terapeutik kepada pasien yang mengalami halusinasi."Yang harus diperhatikan dalam berkomunikasi terapeutik kepada pasien yang mengalami halusinasi adalah posisi, kita harus berhadapan dengan pasien, dan usahakan pasien tidak dalam keadaaan di dalam trali atau pasien dikeluarkan, yang kedua, kontak mata,kemudian berkenalan kepada pasien, mengenalkan nama, menanyakan pasien, perasaannya, baru kita berdiskusi masalah apa yang terjadi pada pasien" (Informan 1).

Komunikasi terapeutik juga harus memperhatikan kondisi kekambuhan pasien hasil indepth menyatkan "Kalau hal-hal yang harus diperhatikan dari perawat paling proteksi diri yaa, karena pasien yang mengalami halusinasi ini ada yang pasien-pasien dengan raptus, itu mungkin kita hanya jaga jarak antara perawat dengan pasiennya, minimal 1 meter" (Informan 5).Peneliti beramsumsi bahwa dalam melakukan komunikasi terapeutik perawat juga perlu memperhatikan proteksi diri perawat tersebut, karena ada kalanya pasien tersebut mengalami raptus dan itu akan membahayakan diri perawat tersebut. Hal ini didukung oleh hasil penelitian Aedil (2013) yang berjudul "Perilaku Petugas Kesehatan Dalam Perawatan Pasien Gangguan Jiwa Skizofrenia Di Rumah Sakit Khusus Daerah Provinsi Sulawesi Selatan Tahun 2013" yang menyatakan bahwa Kondisi yang tidak aman biasanya terjadi akibat adanya pasien skizofrenia yang berperilaku kekerasan. Oleh karena itu, cara yang dilakukan untuk menciptakan rasa aman bagi pasien di ruangan perawatan Kenanga yaitu dengan memfiksasi pasien skizofrenia yang berperilaku kekerasan agar tidak membahayakan perawat dan pasien lainnya yang ada di ruang perawatan. Setelah pasien tenang, barulah perawat menjalin Bina Hubungan Saling Kasih Sayang terhadap pasien dengan cara menyapa, memberi salam, berjabak tangan dan menyebutkan nama pasien. Akan tetapi, tindakan fiksasi yang dilakukan oleh perawat mendapat penilaian negatif dari salah satu pasien bahwa tindakan tersebut membuatnya tidak nyaman. 


\section{KESIMPULAN DAN SARAN}

Kesimpulan

Berdasarkan hasil penelitian tentang penerapan komunikasi terapeutik pada pasien halusinasi dapat disimpulkan bahwa mayoritas diterapkan. Hal ini dipengaruhi oleh lamanya perawat yang bekerja dan tingkat pendidikan perawat di Rumah Sakit Jiwa Tampan Provinsi Riau. Hal tersebut juga diperkuat dengan hasil indepth interview terhadap beberapa perawat pelaksana dan kepala ruangan yang menyatakan bahwa sebagian besar komunikasi terapeutik sudah dilaksanakan.

\section{Saran}

Berdasarkan dari hasil penelitian tersebut terdapat beberapa saran yang dapat di sampaikan peneliti antara lain:

1. Hasil penelitian ini diharapkan dapat menambah pengalaman bagi peneliti khususnya tentang penerapan komunikasi terapeutik pada pasien halusinasi dan ini bisa menjadi langkah awal untuk melakukan penelitian selanjutnya.

2. Diharapkan untuk dapat menambah bukubuku di perpustakaan khususnya tentang penerapan komunikasi terapeutik dan dapat menyediakan media informasi lainnya, sehingga mahasiswa lebih mudah untuk mendapatkan bahan dalam penelitian selanjutnya.

3. Diharapkan bagi pelayanan yang berada di Rumah Sakit Jiwa Tampan Provinsi Riau dapat meningkatkan pengetahuan maupun kualitas dari pelayanan yang sudah selama ini diterapkan di Rumah Sakit Jiwa Tampan Provinsi Riau dan dengan dilakukannya penerapan komunikasi terapeutik ini dapat mengurangi masalah pada pasien yang mengalami gangguan jiwa khususnya pada pasien yang mengalami halusinasi.

\section{DAFTAR PUSTAKA}

Agustin, Ike Mardiati. (2009). "Hubungan Pelaksanaan Komunikasi Terapeutik Dangan Tingkat Kecemasan Pasien Rawat Inap di BP RSUD Kebumen" Jurnal Ilmiah Kesehatan Keperawatan, Vol. 5, No 3, 143-152.
Aedil Muhammad. (2013). Perilaku Petugas Kesehatan Dalam Perawatan Pasien Gangguan Jiwa Skizofrenia Di Rumah Sakit Khusus Daerah Provinsi Sulawesi Selatan Tahun 2013.Jurnal

Aini, Farida, N. (2011). Prevalensi Skizofrenia Paranoid Dengan Gejala Halusinasi di Rumah Sakit Jiwa Dr. Soeharto Heerdjan Jakarta Tahun 2010. Skripsi. Program Sarjana Kedokteran UIN Syarif Hidayatullah Jakarta.

Azizah, Siti dkk (2013). Pengaruh Komunikasi Terapeutik Terhadap Kecemasan Lansia Yang Tingga di Balai Rehabilitasi Sosial "Mandiri" Puncak Gading Semarang. Prosiding Konferensi Nasional PPNI Jawa Tengah 2013.

Diana Sr. R. (2006). Hubungan Pengetahuan Komunikasi Terapeutik Terhadap Kemampuan Komunikasi Perawat dalam Malaksanakan Asuhan Keperawatan di Rumah Sakit Elisabeth Purwokerto. Purwokerto: Jurnal Keperawatan Soedirman. Vol 1 No 2. 18

Hawari, D. (2006). Pendekatan Holistik Pada Gangguan Jiwa Skizofrenia. Jakarta: FKUI

Hidayat, A.A. (2011). Metode Penelitian Keperawatan Dan Analisis Data. Jakarta: Salemba Medika

Husna, A, R. (2009). Hubungan Komunikasi Terapeutik Perawat Dengan Kepuasan Pasien Dalam Pelayanan Keperawatan Di Rumah Sakit Siti Khodijah Sepanjang, Skripsi, Program sarjana UMSurabaya.

Machfoedz, Mahmud. (26 Komunikasi Keperawatan Komunikasi

Terapeutik. Yogyakarta: Ganbika

Mulyaningsih. (2005). Menciptakan Hubungan Terapeutik Antara Perawat Dengan Klien. Jurnal Ilmu Kesehatan STIKES Aisyiyah Surakarta.

Nursalam. (2002). Konsep dan Penerapan Metodologi Penelitian Ilmu Keperawatan.Edisi 2. Jakarta: Salemba Medika 
Parmanda, Kiki. (2013). Gambaran Pengetahuan Masyarakat Tentang Manfaat Bekam Bagi Kesehatan Di RT 03 RW 10 Kelurahan Sidomulyo Barat Kecamatan Tampan Pekanbaru. Karya Tulis Ilmiah. UMRI Pekanbaru.

Sahara, Ervina Siti. (2014). Penerapan Kedisiplinan Menghafal Dalam Meningkatkan Hafalan Siswa Terhadap Juz Amma Pada Pendidikan Diniyah Takmaliyah Awaliyah (PDTA) Ihsan Pekanbaru. Skipsi. STAI Diniyah Pekanbaru.

Stuart, G.W. (2007). Principles and Practice of
Psychiatric Nursing. (6th Edition). St. Louis: Mosby.

Wahyuni. (2011). Gambaran Pengetahuan Mahasiswa DIII Keperawatan Tentang Hubungan Kecerdasan Emosi Dengan Komunikasi Terapeutik Di UMRI. Karya Tulis Ilmiah. UMRI Pekanbaru

Widodo A, (2003). Pendidikan Kesehatan Jiwa Pada Keluarga Penderita Skizofrenia Di Rumah Sakit Jiwa Surakarta, Tesis, Program Pasca Sarjana UGM Yogyakarta.

Yosep, I. (2011). Keperawatan Jiwa. Cetakan 2. bandung: PT RefikaAditama. 